\title{
SEXUAL ACTIVITY IN PATIENTS WITH CARDIAC DISEASES
}

\author{
Marko Mornar Jelavić ${ }^{1,2}$, Goran Krstačić1,3, Aleksandra Perenčević ${ }^{4}$ and Hrvoje Pintariće, \\ ${ }^{1}$ Institute for Cardiovascular Prevention and Rehabilitation, Zagreb, Croatia; \\ ${ }^{2}$ School of Dental Medicine, University of Zagreb, Zagreb, Croatia; ${ }^{3}$ School of Medicine, \\ Josip Juraj Strossmayer University of Osijek, Osijek, Croatia; ${ }^{4}$ Department of Internal Medicine and Dialysis, \\ Zagreb-East Health Center, Zagreb, Croatia; ${ }^{5}$ Cardiac Catheterization Laboratory, \\ Sestre milosrdnice University Hospital Centre, Zagreb, Croatia
}

\begin{abstract}
SUMMARY - In this article, we outline the latest guidelines published by the American Heart Association on sexual activity in patients with coronary artery disease, heart failure, structural heart diseases, arrhythmias, implanted pacemakers or cardioverter defibrillators, as well as on treatment options of sexual dysfunction. Sexual activities are similar to mild/moderate physical activity during a short period. Most patients are recommended to involve in sexual activity after prior comprehensive evaluation of physical condition. Those with stable cardiac symptoms and good functional capacity are at a low risk of adverse cardiovascular events, and others require treatment or stabilization before involving in sexual activity. Stress testing is useful in evaluating safety of sexual activity in patients with questionable or undetermined risk. Treatment of sexual dysfunction includes counseling of patients and their sexual partners, and drug treatment with phosphodiesterase inhibitors (sildenafil, tadalafil, vardenafil) which have been demonstrated to be safe and effective, in men, and with serotonin reuptake inhibitors (flibanserin) and local vaginal estrogen administration in women. In conclusion, in routine clinical practice, patients should be approached individually and multidisciplinarily in order to detect and eliminate the factors that interfere with normal sexual activities and disturb the quality of life.
\end{abstract}

Key words: Cardiovascular diseases; Sexual dysfunction, physiological - drug therapy; Sexual behavior; Quality of life

\section{Introduction}

Erectile and sexual dysfunction in males and females (decreased libido, inability to achieve orgasm, dyspareunia) are independent predictors of adverse cardiovascular events and poorer quality of life (QoL). Both entities have common causal factors such as older age, arterial hypertension, obesity, disorders of glucose and lipid metabolism, metabolic syndrome, smoking and sedentary lifestyle, which individually or synergistically lead to endothelial dysfunction of cardiovascular and reproductive organs. It takes 2 to 5 years from

Correspondence to: Marko Mornar Jelavic, $M D, P h D$, Institute for Cardiovascular Prevention and Rehabilitation, Zagreb, Croatia, Draškovićeva 13, HR-10000 Zagreb, Croatia

E-mail: mjelavic@yahoo.com

Received July 14, 2016, accepted February 6, 2017 sexual dysfunction to evident appearance of some of undesirable cardiovascular events (acute coronary event, stroke, peripheral arterial disease). It could be explained by the smaller caliber of sexual organ blood vessels and thus earlier clinical manifestations of endothelial dysfunction ${ }^{1,2}$. This article brings a review of the latest American Heart Association (AHA) guidelines and other relevant literature about sexual activity (SA) in patients with various cardiac pathology, and treatment options for sexual dysfunction ${ }^{3}$.

\section{Sexual Activity and Acute Cardiovascular Response}

During sexual foreplay and arousal, the values of blood pressure $(\mathrm{BP})$ and heart rate $(\mathrm{HR})$ rise and reach maximum during orgasm. After that, they rapidly de- 
cline to the normal values ${ }^{4-10}$. SA is equal to mild/ moderate physical activity for a short duration (climbing 2 flights of stairs or walking briskly, i.e. with 3-4 metabolic equivalents $(\mathrm{METs}))^{11}$. The values of $\mathrm{HR}$ and systolic BP are usually below $130 \mathrm{bpm}$ and 170 $\mathrm{mm} \mathrm{Hg}$, respectively $\mathrm{y}^{6,12,13}$.

Due to medical or emotional reasons, or older age, some patients may have difficulty reaching orgasm and exert greater demand on their cardiovascular system ${ }^{14}$.

\section{General Recommendations about Sexual Activity in Various Cardiac Diseases}

Initial clinical evaluation in patients with cardiovascular disease (CVD) is necessary before initiating or resuming $\mathrm{SA}$, which is acceptable in a group of subjects with no or minimal symptoms during routine activities and low risk of cardiovascular complications ${ }^{3,15-18}$. This group consists of patients with Canadian Classification System (CCS) class I or II angina; New York Heart Association (NYHA) class I or II heart failure; mild to moderate valve disease; previous myocardial infarction; successful coronary revascularization; most types of congenital heart disease; and ability to achieve $\geq 3-5$ METs during exercise stress testing without angina, ischemic electrocardiographic changes, hypotension, cyanosis, arrhythmia, or excessive dyspnea. In patients with unstable or decompensated heart disease (i.e. unstable angina, decompensated heart failure (HF), uncontrolled arrhythmia, or significantly symptomatic and/or severe valve disease), SA should be deferred until the patient is stabilized and optimally managed ${ }^{3}$. Exercise stress testing is reasonable for patients who have unknown cardiovascular risk to assess exercise capacity and development of symptoms, ischemia, or arrhythmias. Accordingly, SA is acceptable in patients who can achieve $\geq 3-5$ METs without angina, excessive dyspnea, ischemic ST-segment changes, cyanosis, hypotension or arrhythmias ${ }^{3,19}$. Finally, cardiac rehabilitation and regular exercise in patients with CVD are reasonable and can be useful in reducing the risk of complications during SA. It increases the maximum exercise capacity and leads to reduction of maximal coital $\mathrm{BP}$ and $\mathrm{HR}^{13,20}$.

\section{Angina pectoris}

Sexual activity is possible in patients with no or mild angina pectoris (class I or II), while it should be postponed in others until their condition is stabilized or optimally controlled ${ }^{3,15-18}$. In patients with intermediate symptoms or whose risk is unknown, exercise stress testing can provide additional information on exercise tolerance and estimate the severity of ischemia. If the person can achieve energy consumption $\geq 3-5$ METs, then the risk of ischemia during $\mathrm{SA}$ is very low.

\section{Previous myocardial infarction/coronary revascularization}

After myocardial infarction, asymptomatic patients, those without signs of ischemia during exercise stress testing, and subjects with complete coronary revascularization performed are at low cardiovascular risk during SA. Current guidelines suggest beginning of cardiac rehabilitation as soon as possible, and $\mathrm{SA} \geq 1$ weeks after myocardial infarction ${ }^{3}$. SA may be resumed several days after percutaneous coronary intervention, or 6-8 weeks after coronary artery bypass surgery or non-coronary open heart surgery ${ }^{3,15-18,21,22}$. In case of incomplete revascularization, exercise stress testing may provide information on residual ischemia ${ }^{3}$.

\section{Heart failure}

Sexual activity is possible in patients with compensated and/or mild HF (NYHA class I or II) ${ }^{3,23-26}$. Sexual problems occur in $60 \%-87 \%$ of patients with $\mathrm{HF}$, including significant reduction in sexual interest and activity. Sexual dysfunction correlates with symptomatology, but not with ejection fraction. Most patients with $\mathrm{HF}$ give priority to improving QoL (including sexual component) rather than survival ${ }^{27-32}$. Optimal treatment increases the probability of safe and satisfactory SA. Exercise improves QoL and can affect SA. Patients who have shortness of breath or fatigue during SA can be advised to take certain positions during intercourse that reduce the level of physical exertion ${ }^{33-35}$.

\section{Valve disease}

Sexual activity is acceptable only in patients with $\mathrm{mild} /$ moderate valve disease, who are asymptomatic or with mild symptoms, as well as in patients with normal function of artificial valves, and those who have undergone successful trans-catheter valve correction ${ }^{3}$.

Time to resume SA after cardiovascular surgery procedure is discussed below. Exercise stress testing 
can be useful in estimating individuals with asymptomatic moderate or severe aortic stenosis and those with other asymptomatic severe valve dysfunction. Exercise echocardiography can give other helpful information on the physiological response to exercise ${ }^{3}$.

\section{Arrhythmias and electrostimulation}

Sudden cardiac death is very rare during SA in general population ${ }^{36-38}$. The risk of ventricular arrhythmia during $\mathrm{SA}$ in patients with $\mathrm{CVD}$, including those with implanted cardioverter defibrillator (ICD), does not seem to be greater than during comparable physical exertion or stress testing ${ }^{39,40}$. SA is acceptable for patients with atrial fibrillation or flutter and good control of ventricular frequency, with properly controlled supraventricular tachycardia, with pacemakers, with ICD implanted for primary prevention, and those with ICD used for secondary prevention, in whom moderate physical activity ( $\geq 3-5 \mathrm{MET}$ ) does not precipitate ventricular tachycardia or fibrillation and who do not receive frequent multiple appropriate shocks ${ }^{3}$. It is not acceptable in individuals who have more device activation until arrhythmia is stabilized or is not under optimal control ${ }^{3}$. SA often decreases after ICD implantation, primarily due to concerns of patients and partners about the danger of cardiac arrest during sexual intercourse ${ }^{41-43}$. Exercise stress testing can provide proof of enough security to the patient that sexual activity is unlikely to lead to the incidence or worsening of arrhythmias ${ }^{44}$. Also, researches have shown that there is minimal risk of so-called 'electric shock' during ICD activation for partners because it is very small energy that rarely reaches surface of the patient's body ${ }^{45}$.

\section{Congenital heart disease}

Sexual activity is acceptable for most patients who have no decompensated or advanced HF, symptomatic or severe valve disease, and uncontrolled arrhythmias ${ }^{3}$. Published guidelines allow unlimited physical activity for asymptomatic patients with closed or small atrial or ventricular septal defect, mild coarctation of the aorta, closed ductus arteriosus, and other mild congenital defects with normal right-sided heart volume without pulmonary hypertension and without significant outflow tract obstruction of the left or right ventricle $^{46-49}$. Thus, SA may be acceptable in most patients with congenital heart disease. It is doubtful in significant pulmonary hypertension, cyanosis, severe outflow obstruction of left ventricle, uncontrolled arrhythmias, and anomalous coronary artery, which passes between pulmonary artery and aorta.

\section{Hypertrophic cardiomyopathy}

Hypertrophic cardiomyopathy (HCM) is a heterogeneous genetic heart disease and it is the most common cause of arrhythmia-related sudden cardiac death in young people, including athletes ${ }^{50,51}$. About $70 \%$ of patients with HCM have left ventricle outflow obstruction, either during rest or physiological exertion regardless of whether or not there are limiting symptoms $\mathrm{s}^{52,53}$. The connection between physical activity and sudden death is to be assigned to the occurrence of ventricular tachycardia/fibrillation, which raises concerns that strong SA may increase the risk of sudden death in these patients ${ }^{51}$.

However, there are no documented cases of cardiac arrest related to SA in that population. It is in line with the recommendation according to which patients with HCM should not participate in intense competitive sports or similar activities ${ }^{54}$. Thus, $\mathrm{SA}$ is possible in most patients with HCM, and it should be postponed in symptomatic patients with HCM until their condition is stabilized or optimally controlled ${ }^{3}$.

\section{Cardiovascular Drugs and Sexual Function}

Cardiovascular drugs that can relieve symptoms and improve survival should not be avoided because of the concern about their potential impact on sexual function ${ }^{3}$. If the patient complains of sexual dysfunction, then it should be evaluated whether it is associated with primary $\mathrm{CVD}$, cardiovascular drug adverse effect, or it is a consequence of anxiety or depression ${ }^{3}$.

Various cardiovascular drugs can cause erectile dysfunction $(\mathrm{ED})^{3}$. In patients who developed ED during treatment with thiazides and $\beta$-blockers, using Henle's loop diuretics and nebivolol are reasonable alternative. Some males treated with spironolactone can experience antiandrogen side effects with compromised sexual function and activity (e.g., decreased libido, ED, and gynecomastia), and eplerenone may be reasonable alternative ${ }^{55,56}$. Women treated with thiazides and aldosterone may have problems with vaginal lubrication or menstrual irregularities ${ }^{57,58}$. Studies proved positive 
effect of valsartan in improving ED, including orgasmic function, sexual desire and satisfaction with sexual life in patients with arterial hypertension, especially in obese and diabetics. The basic mechanism of this action is the inhibition of local angiotensin converting enzyme, but there are other indirect mechanisms. Appropriate alternative is treating ED with phosphodiesterase inhibitors (PDE5) ${ }^{59}$.

\section{Pharmacotherapy of Sexual Dysfunction}

\section{PDE5-inbibitors}

These medications prevent the breakdown of cGMP and increase the concentration of nitrogen oxide, with vasodilatation and improvement of erectile function $^{3,60-62}$. Tadalafil and sildenafil are used in patients with pulmonary hypertension. There are several main facts about these drugs ${ }^{3,60-62}$, as follows: PDE5-inhibitors are useful in the treatment of ED in patients with stable CVD; safety of treatment with PDE5-inhibitors is unknown in patients with severe aortic stenosis or HCM; PDE5-inhibitors should be avoided in patients treated with organic nitrates; and in patients with chest pain and/or acute coronary syndrome, organic nitrates must be avoided within 24 hours of the application of sildenafil or vardenafil, or for 48 hours after using tadalafil.

Previous studies have not proven that one drug is more effective and/or safer than the others. When used with other cardiovascular drugs, PDE5-inhibitors could be associated with symptomatic hypotension (alpha-blockers) and prolongation of QT-inter$\mathrm{val}^{3,60,62}$.

In 2015, Food and Drug Administration (FDA) approved flibanserin (selective serotonin reuptake inhibitor, SSRI) for treating sexual dysfunction in premenopausal women ${ }^{63-67}$. It can be caused by mental and/or physical factors such as stress and hormonal changes during the woman's life. With the exception of hypotension and syncope, especially in combination with alcohol or liver enzyme CYP3A4-inhibitors, the drug has been proven to be generally safe for use through testing on more than 11,000 women.

\section{Local estrogen therapy}

Estrogen treatment through vagina or vulva is effective for alleviating symptoms of vaginal atrophy and dyspareunia, which usually occur in menopause and postmenopause $\mathrm{e}^{3,68}$. Oral administration of estrogen and progesterone may lead to increased cardiovascular risk, which has been excluded with local estrogen therapy. Moreover, by vaginal application, systemic absorption is minimal by vaginal application and even lower by vulva, so there is no noticeable impact on cardiovascular risk ${ }^{69-71}$.

\section{Herbal drugs}

It may be reasonable to warn patients with CVD of the potential adverse events with the use of herbal medications with unknown ingredients, taken for the treatment of sexual dysfunction ${ }^{3}$. Some of these may contain compounds (e.g., PDE5-inhibitors, yohimbin, or L-arginine) which may interact with cardiovascular drugs, have vasoactive or sympathomimetic effect, cause raise or reduce systemic BP, and are associated with adverse outcomes in patients with coronary artery disease $\mathrm{e}^{72-75}$.

\section{Psychological Problems and Sexual Counseling}

It is necessary to estimate anxiety and depression because a combination of psychological disorders and decreased sexual function is common in $\mathrm{CVD}^{76-79}$. SA or pleasure often declines due to fear of patients or partners who believe that SA would worsen physical status or cause death ${ }^{77,80}$. Counseling by health professionals is necessary and useful to help patients and partners in restoring SA after acute cardiac event, newly diagnosed CVD, or after implantation of the $\mathrm{ICD}^{3,81-85}$. General recommendation is that patients should be involved in sexual activities rested, they should avoid unknown environment and partners in order to reduce stress during SA, avoid consuming heavy meals or alcohol before SA, and practice positions that do not restrict breathing. Each patient should be approached individually, since reaching orgasm may require greater effort and may not be a realistic initial goal in some patients.

\section{Summary of AHA Guidelines and Conclusion}

In CVD patients, complete evaluation of physical condition is recommended prior to involvement in SA. Stable symptoms and good functional capacity carry a 
low risk of adverse cardiovascular events. In others, SA should be postponed until their condition is stabilized or optimally controlled. In subjects with doubtful risk, exercise stress testing can give additional information on the safety of SA. Cardiovascular drugs that can relieve symptoms and improve survival should not be avoided because of the concern about their potential impact on sexual function.

Phosphodiesterase inhibitors are safe and effective in patients with CVD, but contraindicated during treatment with nitrates. Psychological conditions, such as anxiety and/or depression, may have influence on sexual function. Sexual counseling of both patients and their partners has a role in recovery of sexual function and habits.

Further researches of SA in certain CVDs are needed, especially in women and older persons. Future diagnostic, pharmacological and surgical guidelines for treating CVD patients should be much clearer in defining for SA. It is necessary to raise awareness of a multidisciplinary approach, including sexual counseling as one of the most essential items in daily work with these patients and their partners.

\section{References}

1. Nehra A. Erectile dysfunction and cardiovascular disease: efficacy and safety of phosphodiesterase type 5 inhibitors in men with both conditions. Mayo Clin Proc. 2009;84(2):139-48. doi: 10.1016/S0025-6196(11)60822-7.

2. Bailey LA, Hoffman D. Female sexual dysfunction: a nontraditional risk factor for cardiovascular disease. Curr Sex Health Rep. 2008;5(4):208-12.

3. Levine GN, Steinke EE, Bakaeen FG, Bozkurt B, Cheitlin $\mathrm{MD}$, Conti JB, et al.; American Heart Association Council on Clinical Cardiology; Council on Cardiovascular Nursing; Council on Cardiovascular Surgery and Anesthesia; Council on Quality of Care and Outcomes Research. Sexual activity and cardiovascular disease: a scientific statement from the American Heart Association. Circulation. 2012;125(8):1058-72. doi: 10.1161/CIR.0b013e3182447787.

4. Carmichael MS, Warburton VL, Dixen J, Davidson JM. Relationships among cardiovascular, muscular, and oxytocin responses during human sexual activity. Arch Sex Behav. 1994:23:59-79.

5. Exton NG, Truong TC, Exton MS, Wingenfeld SA, Leygraf $\mathrm{N}$, Saller B, et al. Neuroendocrine response to film-induced sexual arousal in men and women. Psychoneuroendocrinology. 2000;25:187-99.

6. Bohlen JG, Held JP, Sanderson MO, Patterson RP. Heart rate, rate-pressure product, and oxygen uptake during four sexual activities. Arch Intern Med. 1984;144:1745-8.
7. Chen X, Zhang Q, Tan X. Cardiovascular effects of sexual activity. Indian J Med Res. 2009;130:681-8.

8. Krüger T, Exton MS, Pawlak C, von zur Mühlen A, Hartmann U, Schedlowski M. Neuroendocrine and cardiovascular response to sexual arousal and orgasm in men. Psychoneuroendocrinology. 1998;23:401-11.

9. Exton MS, Bindert A, Kruger T, Scheller F, Hartmann U, Schedlowski M. Cardiovascular and endocrine alterations after masturbation-induced orgasm in women. Psychosom Med. 1999;61:280-9.

10. Stein RA. Cardiovascular response to sexual activity. Am J Cardiol. 2000;86:27F-29F.

11. Hellerstein HK, Friedman EH. Sexual activity and the postcoronary patient. Arch Intern Med. 1970;125:987-99.

12. Debusk R, Drory Y, Goldstein I, Jackson G, Kaul S, Kimmel $\mathrm{SE}$, et al. Management of sexual dysfunction in patients with cardiovascular disease: recommendations of the Princeton Consensus Panel. Am J Cardiol. 2000;86:175-81.

13. Cheitlin MD. Sexual activity and cardiac risk. Am J Cardiol. 2005;96:24M-28M.

14. Lindau ST, Schumm LP, Laumann EO, Levinson W, O'Muircheartaigh CA, Waite LJ. A study of sexuality and health among older adults in the United States. N Engl J Med. 2007;357:762-74. DOI: 10.1056/NEJMoa067423

15. Dahabreh IJ, Paulus JK. Association of episodic physical and sexual activity with triggering of acute cardiac events: systematic review and meta-analysis. JAMA. 2011;305:1225-33. doi: 10.1001/jama.2011.336

16. Muller JE, Mittleman MA, Maclure M, Sherwood JB, Tofler GH; Determinants of Myocardial Infarction Onset Study Investigators. Triggering myocardial infarction by sexual activity: low absolute risk and prevention by regular physical exertion. JAMA. 1996;275:1405-9.

17. Möller J, Ahlbom A, Hulting J, Diderichsen F, de Faire U, Reuterwall $\mathrm{C}$, et al. Sexual activity as a trigger of myocardial infarction: a case-crossover analysis in the Stockholm Heart Epidemiology Programme (SHEEP). Heart. 2001;86:387-90.

18. DeBusk RF, Blomqvist CG, Kouchoukos NT, Luepker RV, Miller HS, Moss AJ, et al. Identification and treatment of lowrisk patients after acute myocardial infarction and coronaryartery bypass graft surgery. N Engl J Med. 1986;314:161-6.

19. Kostis JB, Jackson G, Rosen R, Barrett-Connor E, Billups K, Burnett AL, et al. Sexual dysfunction and cardiac risk (the Second Princeton Consensus Conference). Am J Cardiol. 2005;96:313-21. DOI: 10.1016/j.amjcard.2005.03.065

20. Stein RA. The effect of exercise training on heart rate during coitus in the post myocardial infarction patient. Circulation. 1977;55:738-40.

21. Papadopoulos C, Shelley SI, Piccolo M, Beaumont C, Barnett L. Sexual activity after coronary bypass surgery. Chest. 1986; 90:681-5.

22. Lukkarinen H, Lukkarinen O. Sexual satisfaction among patients after coronary bypass surgery or percutaneous translumi- 
nal angioplasty: eight-year follow-up. Heart Lung. 2007;36: 262-9. DOI: 10.1016/j.hrtlng.2006.12.001

23. Bocchi EA, Guimarães G, Mocelin A, Bacal F, Bellotti G, Ramires JF. Sildenafil effects on exercise, neurohormonal activation, and erectile dysfunction in congestive heart failure: a double-blind, placebo controlled, randomized study followed by a prospective treatment for erectile dysfunction. Circulation. 2002;106:1097-103.

24. Freitas D, Athanazio R, Almeida D, Dantas N, Reis F. Sildenafil improves quality of life in men with heart failure and erectile dysfunction. Int J Impot Res. 2006;18:210-2. DOI: 10.1038/sj.ijir.3901385

25. Katz SD, Parker JD, Glasser DB, Bank AJ, Sherman N, Wang $\mathrm{H}$, et al. Efficacy and safety of sildenafil citrate in men with erectile dysfunction and chronic heart failure. Am J Cardiol. 2005;95:36-42. DOI: 10.1016/j.amjcard.2004.08.060

26. Webster LJ, Michelakis ED, Davis T, Archer SL. Use of sildenafil for safe improvement of erectile function and quality of life in men with New York Heart Association classes II and III congestive heart failure: a prospective, placebo-controlled, double-blind crossover trial. Arch Intern Med. 2004;164:514-20. doi:10.1001/archinte.164.5.514

27. Rastogi S, Rodriguez JJ, Kapur V, Schwarz ER. Why do patients with heart failure suffer from erectile dysfunction? A critical review and suggestions on how to approach this problem. Int J Impot Res. 2005;17(Suppl. 1):S25-S36.

28. Jaarsma T. Sexual problems in heart failure patients. Eur J Cardiovasc Nurs. 2002;1:61-7.

https://doi.org/10.1016/S1474-5151(01)00009-3

29. Jaarsma T, Dracup K, Walden J, Stevenson LW. Sexual function in patients with advanced heart failure. Heart Lung. 1996; $25: 262-70$

30. Schwarz ER, Kapur V, Bionat S, Rastogi S, Gupta R, Rosanio $\mathrm{S}$. The prevalence and clinical relevance of sexual dysfunction in women and men with chronic heart failure. Int J Impot Res. 2008;20:85-91. doi:10.1038/sj.ijir.3901613

31. Stanek EJ, Oates MB, McGhan WF, Denofrio D, Loh E. Preferences for treatment outcomes in patients with heart failure: symptoms versus survival. J Card Fail. 2000;6:225-32. DOI: 10.1054/jcaf.2000.9503

32. Steinke EE, Wright DW, Chung ML, Moser DK. Sexual selfconcept, anxiety, and self-efficacy predict sexual activity in heart failure and healthy elders. Heart Lung. 2008;37:323-33. DOI: $10.1016 /$ j.hrtlng.2007.09.004

33. Flynn KE, Piña IL, Whellan DJ, Lin L, Blumenthal JA, Ellis SJ, et al.; HF-ACTION Investigators. Effects of exercise training on health status in patients with chronic heart failure: HF-ACTION randomized controlled trial [published correction appears in JAMA. 2009;302:2322]. JAMA. 2009;301: 1451-9. DOI: $10.1001 /$ jama.2009.457

34. Belardinelli R, Lacalaprice F, Faccenda E, Purcaro A, Perna G. Effects of short-term moderate exercise training on sexual function in male patients with chronic stable heart failure. Int J Cardiol. 2005;101:83-90. DOI: 10.1016/j.ijcard.2004.05.020
35. Steinke EE. Intimacy needs and chronic illness: strategies for sexual counseling and self-management. J Gerontol Nurs. 2005;31:40-50.

36. Ueno M. The so-called coition death. Nihon Hoigaku Zasshi. 1963;17:330-40. (in Japanese)

37. Krauland W, Underwarteter T. Herzinfarkt und Sexualität aus der Sicht des Rechtsmediziners. Sexualmedezin.1976;10:20-3. (in German)

38. Parzeller M, Raschka C, Bratzke H. Sudden cardiovascular death during sexual intercourse: results of a legal medicine autopsy study. Z Kardiol. 1999;88:44-8. (in German)

39. Kavanagh T, Shephard RJ. Sexual activity after myocardial infarction. Can Med Assoc J. 1977;116:1250-3.

40. Fries R, König J, Schäfers HJ, Böhm M. Triggering effect of physical and mental stress on spontaneous ventricular tachyarrhythmias in patients with implantable cardioverter-defibrillators. Clin Cardiol. 2002;25:474-8.

41. Steinke EE. Sexual concerns of patients and partners after an implantable cardioverter defibrillator. Dimens Crit Care Nurs. 2003;22:89-96.

42. Mickley H, Petersen J, Nielsen BL. Subjective consequences of permanent pacemaker therapy in patients under the age of retirement. Pacing Clin Electrophysiol. 1989;12:401-5.

43. Steinke EE, Gill-Hopple K, Valdez D, Wooster M. Sexual concerns and educational needs after an implantable cardioverter defibrillator. Heart Lung. 2005;34:299-308. DOI: 10.1016/j.hrtlng.2005.03.002

44. Sears SF, Kovacs AH, Conti JB, Handberg E. Expanding the scope of practice for cardiac rehabilitation: managing patients with implantable cardioverter defibrillators. J Cardiopulm Rehabil. 2004;24:209-15.

45. Vazquez LD, Sears SF, Shea JB, Vazquez PM. Sexual health for patients with an implantable cardioverter defibrillator. Circulation. 2010;122(13):e465-7.

DOI: 10.1161/CIRCULATIONAHA.110.949628

46. Vigl M, Kaemmerer M, Seifert-Klauss V, Niggemeyer E, Nagdyman N, Trigas V, et al. Contraception in women with congenital heart disease. Am J Cardiol. 2010;106:1317-21. DOI: 10.1016/j.amjcard.2010.06.060

47. Vigl M, Hager A, Bauer U, Niggemeyer E, Wittstock B, Köhn $\mathrm{FM}$, et al. Sexuality and subjective wellbeing in male patients with congenital heart disease. Heart. 2009;95:1179-83. DOI: 10.1136/hrt.2008.156695

48. Graham TP Jr, Driscoll DJ, Gersony WM, Newburger JW, Rocchini A, Towbin JA. Task Force 2: Congenital heart disease. J Am Coll Cardiol. 2005;45:1326-33. DOI: $10.1016 /$ j.jacc.2005.02.009

49. Pelliccia A, Fagard R, Bjørnstad HH, Anastassakis A, Arbustini E, Assanelli D, et al.; Study Group of Sports Cardiology of the Working Group of Cardiac Rehabilitation and Exercise Physiology; Working Group of Myocardial and Pericardial Diseases of the European Society of Cardiology. Recommendations for competitive sports participation in athletes with 
cardiovascular disease: a consensus document from the Study Group of Sports Cardiology of the Working Group of Cardiac Rehabilitation and Exercise Physiology and the Working Group of Myocardial and Pericardial Diseases of the European Society of Cardiology. Eur Heart J. 2005;26:1422-45. DOI: 10.1093/eurheartj/ehi325

50. Maron BJ. Hypertrophic cardiomyopathy: a systematic review. JAMA. 2002;287:1308-20.

51. Maron BJ, Doerer JJ, Haas TS, Tierney DM, Mueller FO. Sudden deaths in young competitive athletes: analysis of 1866 deaths in the United States, 1980-2006. Circulation. 2009;119:1085-92.

DOI: 10.1161/CIRCULATIONAHA.108.804617

52. Maron MS, Olivotto I, Betocchi S, Casey SA, Lesser JR, Losi MA, et al. Effect of left ventricular outflow tract obstruction on clinical outcome in hypertrophic cardiomyopathy. N Engl J Med. 2003;348:295-303. DOI: 10.1056/NEJMoa021332

53. Maron MS, Olivotto I, Zenovich AG, Link MS, Pandian NG, Kuvin JT, et al. Hypertrophic cardiomyopathy is predominantly a disease of left ventricular outflow tract obstruction. Circulation. 2006;114:2232-9.

DOI: 10.1161/CIRCULATIONAHA.106.644682

54. Pelliccia A,Zipes DP, Maron BJ. Bethesda Conference \#36 and the European Society of Cardiology Consensus Recommendations revisited: a comparison of U.S. and European criteria for eligibility and disqualification of competitive athletes with cardiovascular abnormalities. J Am Coll Cardiol. 2008;52:1990-6. DOI: $10.1016 /$ j.jacc.2008.08.055

55. Boydak B, Nalbantgil S, Fici F, Nalbantgil I, Zoghi M, Ozerkan F, et al. A randomised comparison of the effects of nebivolol and atenolol with and without chlorthalidone on the sexual function of hypertensive men [published correction appears in Clin Drug Investig. 2007;27:864]. Clin Drug Investig. 2005; 25:409-16.

56. Brixius K, Middeke M, Lichtenthal A, Jahn E, Schwinger RH. Nitric oxide, erectile dysfunction and beta-blocker treatment (MR NOED study): benefit of nebivolol versus metoprolol in hypertensive men. Clin Exp Pharmacol Physiol. 2007;34: 327-31. DOI: 10.1111/j.1440-1681.2007.04551.x

57. Grimm RH Jr, Grandits GA, Prineas RJ, McDonald RH, Lewis CE, Flack JM, et al. Long-term effects on sexual function of five antihypertensive drugs and nutritional hygienic treatment in hypertensive men and women: Treatment of Mild Hypertension Study (TOMHS). Hypertension. 1997;29 (Part 1):8-14.

58. Duncan L, Bateman DN. Sexual function in women: do antihypertensive drugs have an impact? Drug Saf. 1993;8:225-34.

59. Babic Z. The Importance of valsartan in the treatment of hypertonic patients with erectile dysfunction. Cardiol Croat. 2015;10(11-12):290-4.

60. Olsson AM, Persson CA; Swedish Sildenafil Investigators Group. Efficacy and safety of sildenafil citrate for the treatment of erectile dysfunction in men with cardiovascular disease. Int J Clin Pract. 2001;55:171-6.
61. Kloner RA. Cardiovascular effects of the 3 phosphodiesterase -5 inhibitors approved for the treatment of erectile dysfunction. Circulation. 2004;110:3149-55.

DOI: 10.1161/01.CIR.0000146906.42375.D3

62. Morales AM, Mirone V, Dean J, Costa P. Vardenafil for the treatment of erectile dysfunction: an overview of the clinical evidence. Clin Interv Aging. 2009;4:463-72.

63. Simon JA, Kingsberg SA, Shumel B, Hanes V, Garcia M Jr, Sand M. Efficacy and safety of flibanserin in postmenopausal women with hypoactive sexual desire disorder: results of the SNOWDROP trial. Menopause. 2014;21(6):633-40. DOI: 10.1097/GME.0000000000000134

64. DeRogatis LR, Komer L, Katz M, Moreau M, Kimura T, Garcia $\mathrm{M} \mathrm{Jr}$, et al. Treatment of hypoactive sexual desire disorder in premenopausal women: efficacy of flibanserin in the VIOLET study. J Sex Med. 2012;9(4):1074-85.

DOI: $10.1111 / \mathrm{j} .1743-6109.2011 .02626 . x$

65. Jayne C, Simon JA, Taylor LV, Kimura T, Lesko L; SUNFLOWER study investigators. Open-label extension study of flibanserin in women with hypoactive sexual desire disorder. J Sex Med. 2012;9(12):3180-8.

DOI: 10.1111/j.1743-6109.2012.02942.x

66. Thorp J, Simon J, Dattani D, Taylor L, Kimura T, Garcia M Jr, et al.; DAISY trial investigators. Treatment of hypoactive sexual desire disorder in premenopausal women: efficacy of flibanserin in the DAISY study. J Sex Med. 2012;9(3):793-804. DOI: $10.1111 / \mathrm{j} .1743-6109.2011 .02595 . x$

67. Katz M, DeRogatis LR, Ackerman R, Hedges P, Lesko L, Garcia M Jr, et al.; BEGONIA trial investigators. Efficacy of flibanserin in women with hypoactive sexual desire disorder: results from the BEGONIA trial. J Sex Med. 2013;10(7): 1807-15. DOI: $10.1111 /$ jsm.12189

68. Lindau ST, Schumm LP, Laumann EO, Levinson W, O'Muircheartaigh CA, Waite LJ. A study of sexuality and health among older adults in the United States. N Engl J Med. 2007;357:762-74. DOI: 10.1056/NEJMoa067423

69. Hulley S, Grady D, Bush T, Furberg C, Herrington D, Riggs B, et al.; Heart and Estrogen/progestin Replacement Study (HERS) Research Group. Randomized trial of estrogen plus progestin for secondary prevention of coronary heart disease in postmenopausal women. JAMA. 1998;280:605-13.

70. Rossouw JE, Anderson GL, Prentice RL, LaCroix AZ, Kooperberg C, Stefanick ML, et al.; Writing Group for the Women's Health Initiative Investigators. Risks and benefits of estrogen plus progestin in healthy postmenopausal women: principal results from the Women's Health Initiative randomized controlled trial. JAMA. 2002;288:321-33.

71. Ponzone R, Biglia N, Jacomuzzi ME, Maggiorotto F, Mariani L, Sismondi P. Vaginal oestrogen therapy after breast cancer: is it safe? Eur J Cancer. 2005;41:2673-81.

DOI: $10.1016 /$ j.ejca.2005.07.015

72. Kearney T, Tu N, Haller C. Adverse drug events associated with yohimbine-containing products: a retrospective review of the California Poison Control System reported cases. Ann Pharmacother. 2010;44:1022-9. DOI: 10.1345/aph.1P060 
73. Aoki H, Nagao J, Ueda T, Strong JM, Schonlau F, Yu-Jing S, et al. Clinical assessment of a supplement of Pycnogenol and L-arginine in Japanese patients with mild to moderate erectile dysfunction. Phytother Res.2012;26(2):204-7.

DOI: $10.1002 /$ ptr.3462

74. Musso NR, Vergassola C, Pende A, Lotti G. Yohimbine effects on blood pressure and plasma catecholamines in human hypertension. Am J Hypertens. 1995;8:565-71.

DOI: 10.1016/0895-7061(95)00037-P

75. Schulman SP, Becker LC, Kass DA, Champion HC, Terrin ML, Forman S, et al. L-arginine therapy in acute myocardial infarction: the Vascular Interaction with Age in Myocardial Infarction (VINTAGE MI) randomized clinical trial. JAMA. 2006;295:58-64. DOI: 10.1001/jama.295.1.58

76. Kriston L, Gunzler C, Agyemang A, Bengel J, Berner MM; SPARK Study Group. Effect of sexual function on health-related quality of life mediated by depressive symptoms in cardiac rehabilitation: findings of the SPARK project in 493 patients. J Sex Med. 2010;7:2044-55.

77. Friedman S. Cardiac disease, anxiety, and sexual functioning. Am J Cardiol. 2000;86:46F-50F.

78. Moser DK, Dracup K, Evangelista LS, Zambroski CH, Lennie TA, Chung ML, et al. Comparison of prevalence of symptoms of depression, anxiety, and hostility in elderly patients with heart failure, myocardial infarction, and a coronary artery bypass graft. Heart Lung. 2010;39:378-85.

DOI: $10.1016 /$ j.hrtlng.2009.10.017
79. Mosack V, Steinke EE. Trends in sexual concerns after myocardial infarction. J Cardiovasc Nurs. 2009;24:162-70.

DOI: 10.1097/JCN.0b013e318197aaa1

80. Kazemi-Saleh D, Pishgou B, Assari S, Tavallaii SA. Fear of sexual intercourse in patients with coronary artery disease: a pilot study of associated morbidity.J Sex Med. 2007;4:1619-25. DOI: 10.1111/j.1743-6109.2007.00619.x

81. Steinke EE, Swan JH. Effectiveness of a videotape for sexual counseling after myocardial infarction. Res Nurs Health. 2004;27:269-80.

DOI: $10.1002 /$ nur.20022

82. Klein R, Baron E, Klein J, Benbenishty R. The impact of sexual therapy on patients after cardiac events participating in a cardiac rehabilitation program. Eur J Cardiovasc Prev Rehabil. 2007;14:672-8.

DOI: 10.1097/HJR.0b013e3282eea52d

83. Steinke EE, Wright DW. The role of sexual satisfaction, age, and cardiac risk factors in the reduction of post-MI anxiety. Eur J Cardiovasc Nurs. 2006;5:190-6.

DOI: 10.1016/j.ejcnurse.2005.12.002

84. Froelicher ES, Kee LL, Newton KM, Lindskog B, Livingston M. Return to work, sexual activity, and other activities after acute myocardial infarction. Heart Lung. 1994;23:423-5.

85. Dhabuwala CB, Kumar A, Pierce JM. Myocardial infarction and its influence on male sexual function. Arch Sex Behav. 1986;15:499-504.

Sažetak

\section{SEKSUALNA AKTIVNOST U BOLESNIKA SA SRČANIM BOLESTIMA}

\section{Mornar Jelavić, G. Krstačić, A. Perenčević i H. Pintarić}

U ovom preglednom članku donosimo pregled posljednjih smjernica koje je objavilo Američko kardiološko društvo o seksualnoj aktivnosti u bolesnika s koronarnom bolešću, srčanom insuficijencijom, strukturnim bolestima srca, aritmijama, ugrađenim elektrostimulatorom ili kardioverter defibrilatorom, kao i o mogućnostima liječenja seksualne disfunkcije. Seksualna aktivnost je ekvivalent blage/umjerene tjelesne aktivnosti tijekom kratkog vremena. Za većinu bolesnika je preporučljivo da se uključe u seksualne aktivnosti nakon sveobuhvatne procjene fizičkog stanja. Oni sa stabilnim kardijalnim simptomima i dobrom funkcionalnom sposobnošću imaju nizak rizik od neželjenih kardiovaskularnih događaja. Ostali zahtijevaju liječenje ili stabilizaciju prije uključivanja u seksualne aktivnosti. Ergometrijsko testiranje je korisno u procjeni sigurnosti spolne aktivnosti u bolesnika s upitnim ili neodređenim rizikom. Liječenje seksualne disfunkcije uključuje seksualno savjetovanje bolesnika i partnera te farmakološku terapiju kod muškaraca inhibitorima fosfodiesteraze (sildenafil, tadalafil, vardenafil), koji su se pokazali sigurnima i učinkovitima, a u žena inhibitorima ponovne pohrane serotonina (flibanserin) i lokalnom vaginalnom aplikacijom estrogena. Zaključno, bolesnicima u svakodnevnoj kliničkoj praksi treba pristupiti individualno i multidisciplinarno u cilju otkrivanja i otklanjanja čimbenika koji ometaju normalnu spolnu aktivnost i dovode do narušavanja kvalitete života.

Ključne riječi: Kardiovaskularne bolesti; Seksualna disfunkcija, fiziološka - farmakoterapija; Seksualno ponašanje; Kvaliteta života 